\title{
Enhanced cAMP Response of Naturally Occurring Mutant of Human $\beta_{3}$-Adrenergic Receptor
}

\author{
Masafumi Isogaya ${ }^{\#}$, Taku Nagao and Hitoshi Kurose* \\ Laboratory of Pharmacology and Toxicology, Graduate School of Pharmaceutical Sciences, University of Tokyo, \\ 7-3-1 Hongo, Bunkyo-ku, Tokyo 113-0033, Japan
}

Received October 2, 2001 Accepted December 12, 2001

\begin{abstract}
We have examined the functional significance of the naturally occurring mutation at position 64 of human $\beta_{3}$-adrenergic receptor $\left(\beta_{3} \mathrm{AR}\right)$, which changes the amino acid from tryptophan to arginine (W64R- $\beta_{3} \mathrm{AR}$ ). The affinities of $\beta \mathrm{AR}$ agonists for W64R- $\beta_{3} \mathrm{AR}$ expressed in COS-7 cells were not significantly different from those for wild type $\beta_{3} \mathrm{AR}$. When two receptors are expressed at various expression levels, and stimulated with CGP12177A, they showed essentially the same $\mathrm{EC}_{50}$ values and maximal responses. Overexpression of $G_{i}$ and $G_{o}$, or the treatment with pertussis toxin did not affect the agonistinduced cAMP response, suggesting that $\mathrm{G}_{\mathrm{i}}$ and $\mathrm{G}_{\mathrm{o}}$ did not contribute to the $\beta_{3} \mathrm{AR}$-induced cAMP response. However, the enhanced cAMP response was observed when W64R- $\beta_{3}$ AR was coexpressed with the adenylyl cyclase type III isoform, and stimulated by CGP12177A and isoproterenol. These results indicate that the cAMP response of W64R- $\beta_{3} \mathrm{AR}$ can be enhanced under the particular condition that adenylyl cyclase type III was coexpressed.
\end{abstract}

Keywords: $\beta_{3}$-Adrenergic receptor, Adenylyl cyclase isoform, Polymorphism, $\beta$-Adrenergic receptor agonist, cAMP production

The $\beta_{3}$-adrenergic receptor $\left(\beta_{3} \mathrm{AR}\right)$ belongs to a superfamily of $\mathrm{G}$ protein-coupled receptors and is mainly expressed in adipose tissue and the gastrointestinal tract (1). Stimulation of $\beta_{3} \mathrm{AR}$ activates adenylyl cyclase (AC) and increases the intracellular concentration of cAMP, leading to lipolysis and thermogenesis. $\beta_{3} \mathrm{AR}$ agonists are envisioned as one of the anti-obesity drugs (2).

Three groups independently reported that the mutation of tryptophan to arginine at position 64 of human $\beta_{3} \mathrm{AR}$ (W64R- $\beta_{3} \mathrm{AR}$ ) correlates with obesity, glucose intolerance, hypertension, dyslipidemia and early onset of non-insulindependent diabetes mellitus $(3-5)$. However, the functional significance of the mutation remains an unsolved issue. Candelore et al. have examined ligand binding, activation of $\mathrm{AC}$ and desensitization pattern, and they found that the biochemical characteristics of W64R- $\beta_{3} \mathrm{AR}$ are essentially the same as those of wild type (WT)- $\beta_{3} \mathrm{AR}(6)$. In contrast to their report, Pietri-Rouxel et al. reported that the degree of maximal cAMP response by W64R- $\beta_{3} \mathrm{AR}$ stimulation is lower than that by WT- $\beta_{3} \mathrm{AR}$ stimulation (7). They also

\#Present address: Basic Research Laboratories, Toray Industries, Inc., 1111 Tebiro, Kamakura, Kanagawa 248-8555, Japan

*Corresponding author. FAX: +81-3-5841-4867

E-mail: kurose@mol.f.u-tokyo.ac.jp showed that the ligand binding characteristics of agonists and antagonists for W64R- $\beta_{3} \mathrm{AR}$ and the half maximal concentrations of agonists to activate W64R- $\beta_{3} \mathrm{AR}$ are same as those of WT- $\beta_{3} \mathrm{AR}$ (7). There is a difference in assay system between the two groups: one group used a pool of cells that showed resistance to antibiotics, and the other group used clonal cell lines that stably expressed receptors. Thus, it remains to be determined whether W64R- $\beta_{3} \mathrm{AR}$ has a decreased or increased ability to induce the cAMP response. Granneman reported that the AC type III isoform (AC-III) is selectively increased in brown adipose tissue by neural stimulation or by cold exposure (8). Therefore, it is also necessary to compare the $\beta_{3} \mathrm{AR}$ mediated responses under the condition that the expression of AC-III is increased. In the present study, we report that W64R- $\beta_{3} \mathrm{AR}$ shows an enhanced cAMP response compared with WT- $\beta_{3} \mathrm{AR}$, when W64R- $\beta_{3} \mathrm{AR}$ is coexpressed with AC-III.

\section{MATERIALS AND METHODS}

Materials
$\left[{ }^{125} \mathrm{I}\right]$ Iodocyanopindolol $\left(\left[{ }^{125} \mathrm{I}\right] \mathrm{ICYP}\right)(2,200 \mathrm{Ci} / \mathrm{mmol})$
and $\left[{ }^{3} \mathrm{H}\right]$ adenine $(24.0-27.0 \mathrm{Ci} / \mathrm{mmol})$ were obtained 
from Amersham Pharmacia Biotech (Arlington Heights, IL, USA). $\left[{ }^{14} \mathrm{C}\right] \mathrm{cAMP}(20.0-50.1 \mathrm{mCi} / \mathrm{mmol})$ was obtained from Perkin Elmer Life Sciences (Boston, MA, USA). The mammalian expression vector pEF-BOS was a gift from Dr. S. Nagata (Osaka University, Osaka). The plasmids encoding for $\beta_{1}$ and $\gamma_{2}$ subunits of heterotrimeric $\mathrm{G}$ protein were kindly provided by Dr. S. Hoshino (University of Tokyo, Tokyo). The plasmids encoding the various $\mathrm{AC}$ isoforms were kindly provided by the following persons: AC-1, from Dr. R.T. Premont (Duke University Medical Center, Durham, NC, USA); AC-II and AC-III, from Dr. R.R. Reed (John Hopkins School of Medicine, Baltimore, MD, USA); and AC-VI, from Dr. Y. Ishikawa (Yokohama City University School of Medicine, Yokohama). CGP12177A, (-)isoproterenol $\cdot \mathrm{HCl}$ and DEAEdextran were from Sigma-Aldrich (St. Louis, MO, USA). Fetal bovine serum was obtained from JRH Biosciences (Lenexa, KS, USA). Pfu DNA polymerase was from Stratagene (La Jolla, CA, USA). Sources of other reagents were mentioned in the previous report (9).

\section{Construction and expression of WT- $\beta_{3} A R$ and mutant $\beta_{3} A R$}

Human WT- $\beta_{3}$ AR gene was cloned from HeLa genomic DNA by the polymerase chain reaction (PCR), and the second exon containing 6 amino acids at the carboxyl terminus was introduced by PCR as described (10). The mutation at position 64 (arginine instead of tryptophan) was introduced by PCR. The entire coding regions of WTand W64R- $\beta_{3} \mathrm{ARs}$ were inserted into expression vector pEF-BOS (11). These two $\beta_{3} \mathrm{AR}$ constructs were used for transfection into COS-7 cells or JEG-3 cells by the DEAE-dextran method as described (12). Cells were plated onto a $100-\mathrm{mm}$ dish for transfection. When $\beta_{3} \mathrm{AR}$ was cotransfected with $\mathrm{G}_{\mathrm{o}}$ or $\mathrm{AC}$ isoform, $1 \mu \mathrm{g}$ of $\mathrm{G}_{\alpha \mathrm{o}}$ in pcDNA3 together with $\mathrm{G}_{\beta 1}$ in pCMV5, $\mathrm{G}_{\gamma 2}$ in pCMV5 and $5 \mu \mathrm{g}$ of AC-I, -II, -III or -VI were used.

\section{Radioligand binding assay}

The crude membrane fraction from the transfected cells was prepared as described (9). Approximately $10 \mu \mathrm{g}$ of membrane protein was used for radioligand binding studies, and $50 \mathrm{pM}\left[{ }^{125} \mathrm{I}\right] \mathrm{ICY}$ was used for competition binding assays. Nonspecific binding was determined in the presence of $1 \mathrm{mM} \mathrm{CGP12177A.}$

Determination of CAMP content in COS-7 and JEG-3 cells

The transfected COS-7 and JEG-3 cells were split into 6-well plates and incubated overnight $\left(37^{\circ} \mathrm{C}, 5 \% \mathrm{CO}_{2}\right)$ in culture medium containing $1 \mu \mathrm{Ci} / \mathrm{ml}\left[{ }^{3} \mathrm{H}\right]$ adenine. The cells were stimulated in DMEM medium containing $20 \mathrm{mM}$ HEPES (pH 7.4), 1 mM 3-isobutyl-1-methyxanthine and the various concentrations of agonists for $15 \mathrm{~min}$ at $37^{\circ} \mathrm{C}$. The reaction was stopped, and generated $\left[{ }^{3} \mathrm{H}\right] \mathrm{cAMP}$ was iso- lated as described (12). The cAMP production was calculated as the ratio of $\left[{ }^{3} \mathrm{H}\right] \mathrm{cAMP}$ to total $\left[{ }^{3} \mathrm{H}\right]$ nucleotides per well (cAMP\%/well) or normalized as fold stimulation, setting cAMP content without agonist as 1.0.

\section{Data analyses}

All data shown are mean values \pm S.E.M. from three or four independent experiments. Equilibrium dissociation constants were determined from saturation isotherms, and competition curves were analyzed by a non-linear regression analysis using PRISM software (GraphPAD Software Inc., San Diego, CA, USA). The statistical significance was assessed with the $t$ test or Dunnett's test.

\section{RESULTS}

\section{Ligand binding characteristics}

The affinities of various drugs for WT- or W64R- $\beta_{3}$ ARs were determined by ligand binding assay. The dissociation constant $\left(\mathrm{K}_{\mathrm{d}}\right)$ of ICYP for W64R- $\beta_{3} \mathrm{AR}$ was similar to the value of WT- $\beta_{3}$ AR (Table 1). Table 1 also shows that $\mathrm{K}_{\mathrm{i}}$ values of the various agonists for W64R- $\beta_{3} \mathrm{AR}$ are essentially the same as those for WT- $\beta_{3} \mathrm{AR}$. Thus, pharmacological characteristics of W64R- $\beta_{3} \mathrm{AR}$ are similar to those of WT- $\beta_{3} \mathrm{AR}$.

\section{Basal and receptor-stimulated cAMP responses}

As CGP12177A is a partial agonist for $\beta_{3} \mathrm{AR}$ and an antagonist for $\beta_{1}$ - and $\beta_{2} \mathrm{ARs}$, COS-7 cells did not respond to CGP12177A stimulation when the cells were not transfected with $\beta_{3} \mathrm{AR}$ (Fig. 1). Stimulation by CGP12177A increased cAMP content in a dose-dependent manner in WT- and W64R- $\beta_{3} \mathrm{AR}$-expressing cells, and the $\mathrm{EC}_{50}$ value of CGP12177A to induce cAMP response of W64R- $\beta_{3} \mathrm{AR}$ was essentially the same as that of WT- $\beta_{3} \mathrm{AR}$ (Fig. 1). As the basal and agonist-stimulated cAMP accumulation is

Table 1. Ligands binding parameters of iodocyanopindolol, isoproterenol, norepinephrine, epinephrine and CGP12177A at the wild type and mutant $\beta_{3}$-AR

\begin{tabular}{lccc}
\hline & & $\begin{array}{c}\text { Wild type } \\
\text { WT- } \beta_{3} \text {-AR }\end{array}$ & $\begin{array}{c}\text { Mutant } \\
\text { W64R- } \beta_{3} \text {-AR }\end{array}$ \\
\hline Iodocyanopindolol & $\mathrm{K}_{\mathrm{d}}(\mathrm{nM})$ & & \\
\hdashline & & $40.3 \pm 3.1$ & $57.9 \pm 2.3$ \\
(-)Isoproterenol & $\mathrm{K}_{\mathrm{i}}(\mathrm{nM})$ & & \\
(-)Norepinephrine & & $270 \pm 34$ & $360 \pm 53$ \\
(-)Epinephrine & & $6000 \pm 330$ & $10000 \pm 780$ \\
CGP12177A & & $1400 \pm 140$ & $2600 \pm 310$ \\
\hline
\end{tabular}

$\left[{ }^{125} \mathrm{I}\right] \mathrm{ICYP}$ binding was determined on the membrane from COS-7 cells expressing the wild type or mutant $\beta_{3}$-AR. 


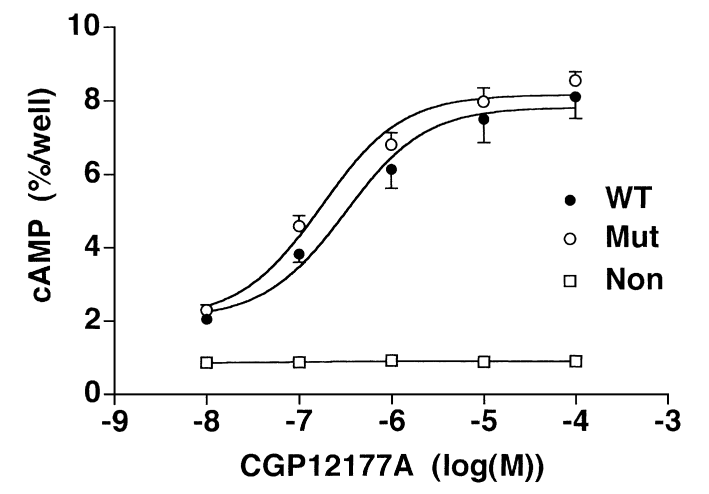

Fig. 1. The cAMP accumulation in COS-7 cells expressing wild type or mutant $\beta_{3} \mathrm{AR}$. cAMP accumulation dose-response curves for wild type (WT)- and mutant (Mut)-receptor transfected COS-7 cells, stimulated with CGP12177A (10 nM $-0.1 \mathrm{mM})$. Non: non-receptorexpressing COS-7 cells.

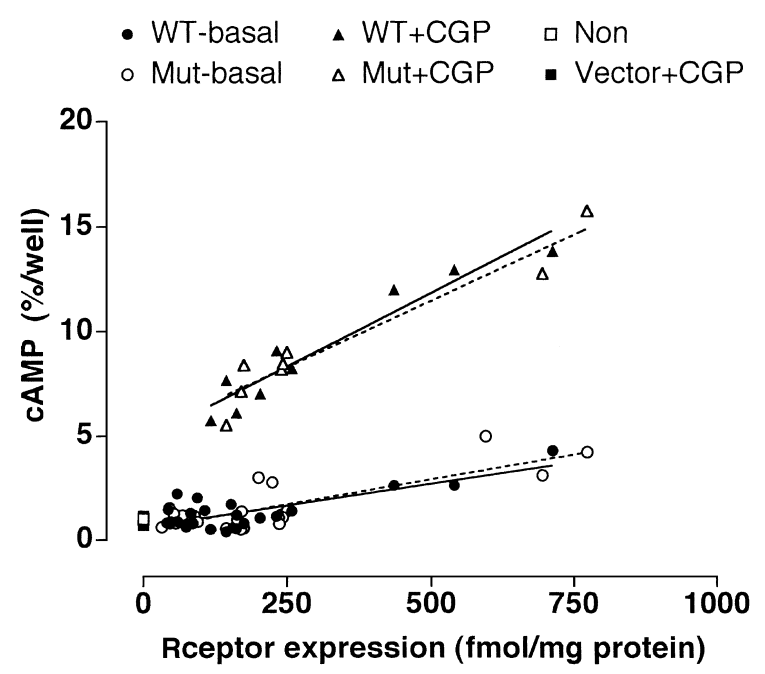

Fig. 2. Effcet of receptor density on basal and CGP-stimulated adenylyl cyclase (AC) activity. The AC activity was measured in membranes derived from COS-7 cells transiently expressing WT (WT: solid circles, solid triangles)- or W64R (Mut: open circles, open triangles)- $\beta_{3} \mathrm{ARs}$ at different receptor densities. The concentration of CGP12177A was $0.1 \mathrm{mM}$. The results are from 4 independent experiments assayed in duplicate. The solid lines indicate that the basal and CGP12177A-stimulated values for WT- $\beta_{3} \mathrm{AR}$, and the dashed lines indicate the basal and CGP12177A-stimulated cAMP contents for W64R- $\beta_{3} \mathrm{AR}$. Non: non-receptor-expressing COS-7 cells.

related to the expression level of the receptor, we determined the basal and CGP12177A-stmulated cAMP responses of WT- and W64R- $\beta_{3}$ ARs at the various expression levels. Figure 2 shows that the basal and CGP12177Astimulated cAMP responses for two receptors are gradually increased by the increasing level of expression. The cAMP responses with or without CGP12177A were essentially the same between two $\beta_{3}$ ARs. This result indicates that W64R- $\beta_{3} \mathrm{AR}$ activates $\mathrm{G}_{\mathrm{s}}$ in similar potency and efficacy to WT- $\beta_{3} \mathrm{AR}$.

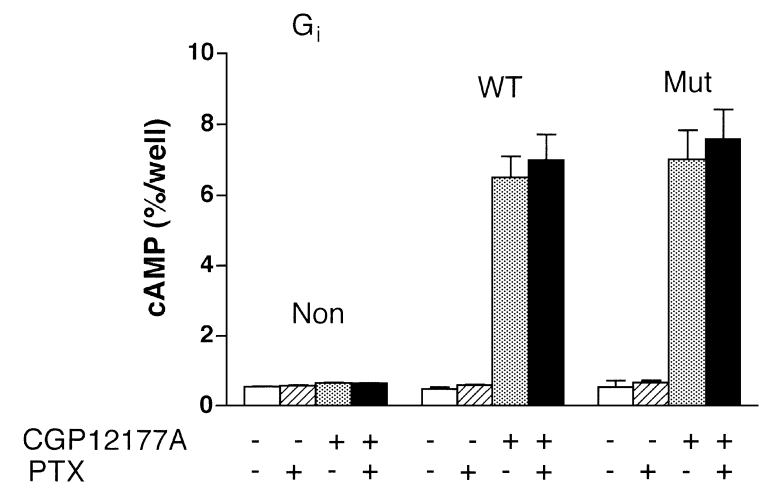

Fig. 3. Effect of pertussis toxin (PTX) on cAMP accumulation in WT- and W64R- $\beta_{3}$ ARs coexpressed with $\mathrm{G}_{i}$ protein in COS-7 cells. WT- and W64R (Mut)- $\beta_{3}$ ARs were stimulated with $0.1 \mathrm{mM}$ CGP12177A. Non: non-receptor-expressing COS-7 cells.

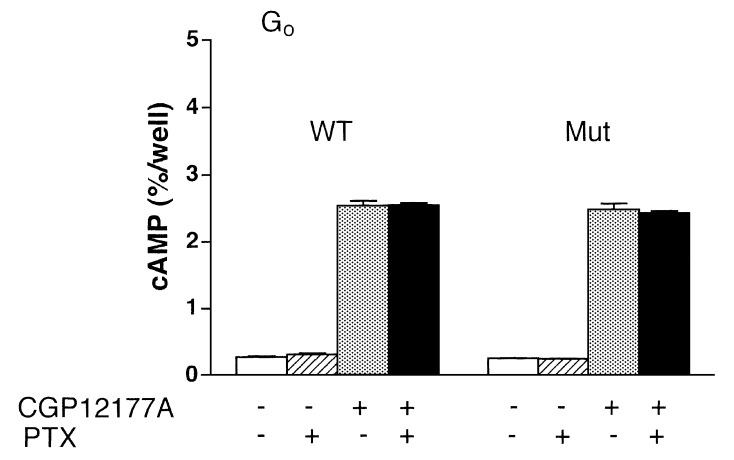

Fig. 4. Effect of pertussis toxin (PTX) on cAMP accumulation in WT- and W64R- $\beta_{3}$ ARs coexpressed with $\mathrm{G}_{0}$ in COS-7 cells. WTand W64R (Mut)- $\beta_{3}$ ARs were co-transfected with $\mathrm{G}_{\mathrm{o}}$ in COS-7 cells,

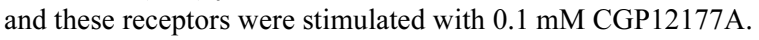

To examine the involvement of $G_{i}$ and $G_{0}$ in the CGP12177A-stimulated cAMP accumulation, we determined the role of $\mathrm{G}_{i}$ and $\mathrm{G}_{0}$ in the basal and CGP12177Astimulated cAMP accumulation. To amplify the $\mathrm{G}_{\mathrm{i}^{-}}$and $\mathrm{G}_{\mathrm{o}}$-mediated signal, we expressed $\beta_{3} \mathrm{AR}$ together with $\mathrm{G}_{\mathrm{i}}$ (expressed as $\alpha_{\mathrm{i} 2} \cdot \beta_{1} \cdot \gamma_{2}$ ) or $\mathrm{G}_{\mathrm{o}}$ (expressed as $\alpha_{\mathrm{o}} \cdot \beta_{1} \cdot \gamma_{2}$ ). In $\mathrm{G}_{\mathrm{i}}$-over-expressing cells, the basal and CGP12177Astimulated cAMP responses by W64R- $\beta_{3}$ AR stimulation were essentially the same as those by WT- $\beta_{3}$ AR stimulation. Pertussis toxin (PTX) treatment did not affect the basal and CGP12177A-stimulated cAMP responses (Fig. 3). When COS-7 cells were not transfected with $\beta_{3} \mathrm{AR}$, CGP12177A stimulation did not increase cAMP accumulation in the PTX-treated cells. This result indicates that PTX treatment itself does not affect the level or function of components involved in the $\beta_{3} \mathrm{AR} / \mathrm{G}_{\mathrm{s}} / \mathrm{AC}$ system. The treatment of W64R- $\beta_{3} \mathrm{AR}$ and $\mathrm{G}_{\mathrm{i}}$ - but not $\mathrm{G}_{\mathrm{o}^{-}}$-over-expressing cells with PTX slightly but not significantly enhanced the cAMP response induced by CGP12177A stimulation (Fig. 4). 

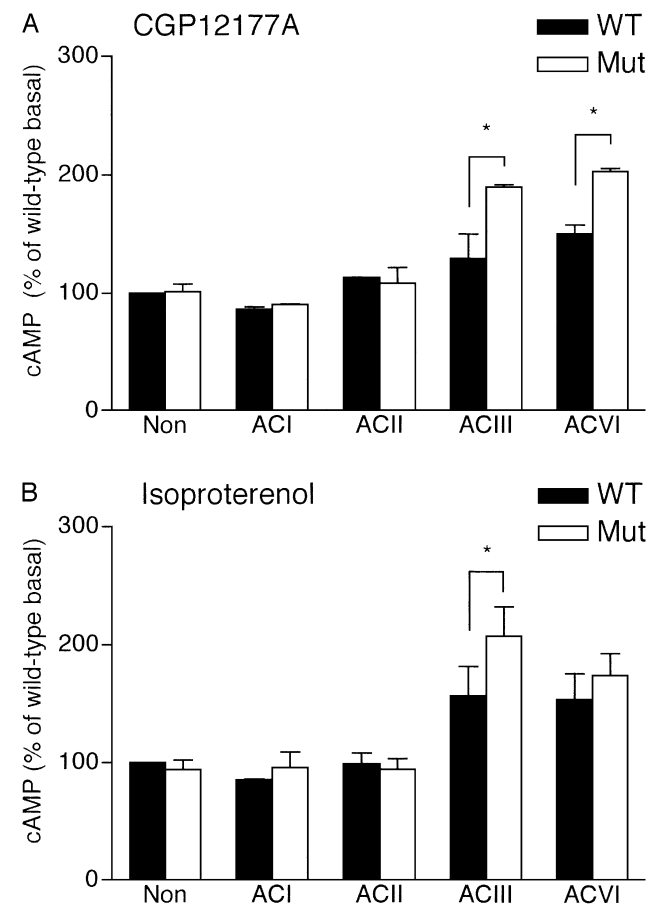

Fig. 5. Effect of co-transfection with $\mathrm{AC}$ isoforms on cAMP accumulation in WT- and W64R- $\beta_{3}$ ARs in JEG-3 cells. WT- and W64R (Mut)- $\beta_{3}$ ARs were co-transfected with AC-I, AC-II, AC-III or AC-VI in JEG-3 cells, and these receptors were then stimulated with $0.1 \mathrm{mM}$ CGP12177A (A) or $0.1 \mathrm{mM}$ isoproterenol (B). ${ }^{*} P<0.05$

\section{AC co-transfection}

As neural stimulation of and cold exposure to brown adipose tissue selectively increases the expression of ACIII among AC-III, IV, V and VI (8), we examined the CGP12177A-induced cAMP response in cells expressing WT- or W64R- $\beta_{3}$ ARs under this particular condition. Therefore, WT- and W64R- $\beta_{3}$ ARs were co-expressed with AC-I, -II, -III or -VI in JEG-3 cells. As COS-7 but not JEG-3 cells express endogenous $\beta$ AR, JEG-3 cells were used for stimulation by the full agonist isoproterenol. When W64R- $\beta_{3} \mathrm{AR}$ was coexpressed with AC-III and ACVI, CGP12177A stimulation enhanced the cAMP response as compared to WT- $\beta_{3} \mathrm{AR}$ co-expressing with $\mathrm{AC}-\mathrm{III}$ and AC-VI (Fig. 5A). When W64R- $\beta_{3} \mathrm{AR}$ was stimulated by isoproterenol, the cAMP response was enhanced in ACIII-expressing cells (Fig. 5B). Co-transfection of AC-VI slightly but not significantly enhanced the isoproterenolinduced increase in cAMP accumulation. These results indicate that co-expression of W64R- $\beta_{3} \mathrm{AR}$ with $\mathrm{AC}-\mathrm{III}$ enhances the agonist-induced cAMP response as compared to co-expression of WT- $\beta_{3} \mathrm{AR}$ with AC-III.

\section{DISCUSSION}

It has been reported that the mutation of tryptophan to arginine at position 64 of human $\beta_{3} \mathrm{AR}$ is associated with obesity, glucose intolerance, hypertension, dyslipidemia and early onset of non-insulin-dependent diabetes mellitus (2). However, two groups reported different results of biochemical characterization of mutated $\beta_{3} \mathrm{AR}$ (W64R$\left.\beta_{3} \mathrm{AR}\right)$. Pietri-Rouxel et al. reported the decreased ability of W64R- $\beta_{3} \mathrm{AR}$ to maximally activate $\mathrm{AC}$ (7). In contrast to their report, Candelore et al. did not observe any significant differences between WT- and W64R- $\beta_{3} \mathrm{AR}$ (6). In the present study, we compared the biochemical and pharmacological characteristics of W64R- $\beta_{3}$ AR to those of WT$\beta_{3} \mathrm{AR}$. We used a transient assay system to avoid clonal variation of receptor-expressing cells. The binding experiments showed that the affinities of various agonists for W64R- $\beta_{3} \mathrm{AR}$ were essentially the same as that of WT$\beta_{3} \mathrm{AR}$. This result is consistent with those of the previous reports.

Basal and CGP12177A-stimulated cAMP responses of W64R- $\beta_{3} \mathrm{AR}$ were almost the same as those of WT- $\beta_{3} \mathrm{AR}$. As the receptor-stimulated cAMP response is affected by the expression level of receptors, we determined the responses at various expression levels of the two $\beta_{3}$ ARs. We did not observe significant differences of basal and CGP12177A-induced cAMP responses between W64Rand WT- $\beta_{3}$ ARs. This result supports the conclusion of Candelore et al. (6), in which they did not detect any significant biochemical and pharmacological differences between the two receptors. Several groups reported that $\beta_{3} \mathrm{AR}$ interacts not only with $\mathrm{G}_{\mathrm{s}}$ but also with $\mathrm{G}_{\mathrm{i}}(13-15)$ and found that $\beta_{3} \mathrm{AR}$ activates extracellular receptor-regulated kinase in a $\mathrm{G}_{\mathrm{i}}$-dependent manner $(13,14)$. Gauthier et al. reported that $G_{i}$ is involved in $\beta_{3}$ AR-mediated signaling in the heart (15). Therefore, we examined whether the functional contribution of $G_{i}$ and $G_{o}$ explains the decreased ability of W64R- $\beta_{3}$ AR to increase cAMP content. PTX treatment did not affect WT- and W64R- $\beta_{3}$ AR-induced cAMP responses even under the condition that $G_{i}$ and $G_{o}$ were over-expressed in a heterotrimeric form. This result suggests that coupling of two $\beta_{3} \mathrm{ARs}$ with $\mathrm{G}_{\mathrm{i}}$ and $\mathrm{G}_{\mathrm{o}}$ did not contribute to the cAMP response in COS-7 cells. Although we could not observe any functional differences between the two $\beta_{3}$ ARs, we have found a difference between WTand W64R- $\beta_{3}$ AR-mediated cAMP responses under a particular condition. Granneman demonstrated that rat brown adipose tissue expresses four kinds of $\mathrm{AC}$ isoforms, and the level of mRNA for AC-III is selectively increased by stimulation of the sympathetic nervous system (8). When AC-III was co-expressed with W64R- $\beta_{3} \mathrm{AR}$, CGP12177Aand isoproterenol-stimulated cAMP responses were significantly enhanced as compared to cAMP response in the cells expressing WT- $\beta_{3} \mathrm{AR}$ and AC-III. However, the isoproterenol-stimulated cAMP response in W64R- $\beta_{3} \mathrm{AR}$ co-expressing AC-VI was slightly but not significantly 
enhanced, in contrast to co-expression with AC-III. CGP12177A is a partial agonist and isoproterenol is a full agonist. AC-VI but not AC-III is phosphorylated by protein kinase A, and the activity is impaired by the phosphorylation. Therefore, it is possible that isoproterenol stimulation slightly decreases AC-VI activity by protein kinase A activation. Although the expression levels of $\beta_{3} \mathrm{ARs}$ and $\mathrm{AC}$ are important determinansts for the receptor-mediated cAMP response, basal cAMP responses are essentially the same between WT- and W64R- $\beta_{3}$ ARs- expressing cells in $\mathrm{AC}-\mathrm{III}$ and AC-VI expressing cells. Therefore, it is reasonable to conclude that the expression levels of $\beta_{3} \mathrm{ARs}$ and $\mathrm{AC}$ are similar to each other, and the differential expression is not enough to explain the enhanced cAMP response induced by W64R- $\beta_{3} \mathrm{AR}$ stimulation. Guan et al. demonstrated that third intracellular loop of $\beta_{3} \mathrm{AR}$ is a critical region for coupling of $\beta_{3} \mathrm{AR}$ with $\mathrm{G}_{\mathrm{s}}$ (16). Because the mutation at position 64 is located at the first intracellular loop, this amino acid may directly participate in the interaction with $\mathrm{G}_{\mathrm{s}}$ as previously suggested. As AC-III shows a modestly high turnover number of cAMP synthesis (17), the small increase in coupling efficiency of $\beta_{3} \mathrm{AR}$ of W64R- $\beta_{3} \mathrm{AR}$ to $\mathrm{G}_{\mathrm{s}}$ may become apparent in the presence of AC-III. One of the consequences of the differential cAMP responses of WT- $\beta_{3} \mathrm{AR}$ and W64R- $\beta_{3} \mathrm{AR}$ is downregulation of $\beta_{3} \mathrm{ARs}$. Because downregulation of $\beta_{3} \mathrm{AR}$ is dependent on cAMP content (18), W64R- $\beta_{3}$ AR may downregulate faster than $\mathrm{WT}-\beta_{3} \mathrm{AR}$ under the condition that AC-III is co-expressed.

In conclusion, the mutated $\beta_{3} \mathrm{AR}$ at position 64 (W64R$\left.\beta_{3} \mathrm{AR}\right)$ did not show any pharmacological and functional differences from WT- $\beta_{3} \mathrm{AR}$. However, W64R- $\beta_{3} \mathrm{AR}$ showed the enhanced cAMP response when AC-III is co-expressed together with the receptor. It remains to be determined whether this difference plays a role in regulation of $\beta_{3} \mathrm{AR}$ in vivo.

\section{Acknowledgments}

We would like to thank Drs. S. Nagata, S. Hoshino, R.T. Premont, R.R. Reed and Y. Ishikawa for providing the plasmids used in this study. This research was supported in part by a Grant-in-Aid for Scientific Research from the Ministry of Education, Culture, Sports, Science and Technology, Japan.

\section{REFERENCES}

1 Emorine LJ, Marullo S, Briend-Sutren M-M, Patey G, Tate K, Delavier-Klutchko $\mathrm{C}$ and Strosberg AD: Molecular characterization of the human $\beta_{3}$-adrenergic receptor. Science $\mathbf{2 4 5}$, $1118-1121$ (1989)

2 Strosberg AD: Association of $\beta_{3}$-adrenoceptor polymorphism with obesity and diabetes: current status. Trends Pharmacol Sci 18, 449 - 454 (1997)

3 Clemen K, Vaisse C, Manning BS, Basdevant A, Guy-Grand B, Ruiz J, Silver KD, Shuldiner AR, Frognel P and Strosberg AD:
Genetic variation in the $\beta_{3}$-adrenergic receptor and increased capacity to gain weight in patients with morbid obesity. New Engl J Med 333, 352 - 354 (1995)

4 Walston J, Silver K, Bogardus C, Knowler WC, Celi FS, Austin S, Manning BS, Strosberg AD, Stern MP, Raben N, Sorkin JD, Roth J and Shuldiner AR: Time of onset of non-insulindependent diabetes mellitus and genetic variation in the $\beta_{3^{-}}$ adrenergic-receptor gene. New Engl J Med 333, 343-347 (1995)

5 Widen E, Lehto M, Kanninen T, Walston J, Shuldiner AR and Groop LC: Association of a polymorphism in the $\beta_{3}$-adrenergicreceptor gene with features of the insulin resistance syndrome in Finns. New Engl J Med 333, 348 - 351 (1995)

6 Candelore MR, Deng L, Tota LM, Kelly LJ, Cascieri MA and Strader CD: Pharmacological characterization of a recently described human $\beta_{3}$-adrenergic receptor mutant. Endocrinology 137, 2638 - 2641 (1996)

7 Pietri-Rouxel F, Manning BS, Gros J and Strosberg AD: The biochemical effect of the naturally occurring Trp-Arg mutation on human $\beta_{3}$-adrenoceprtor activity. Eur J Biochem 247, $1174-1179$ (1997)

8 Granneman JG: Expression of adenylyl cyclase subtypes in brown adipose tissue: neural regulation of type III. Endocrinology 136, 2007 - 2012 (1995)

9 Isogaya M, Yamagiwa Y, Fujita S, Sugimoto Y, Nagao T and Kurose H: Identification of a key amino acid of the $\beta_{2}$-adrenergic receptor for high affinity binding of salmeterol. Mol Pharmacol 54, 616 - 622 (1998)

10 Sato $\mathrm{Y}$, Kurose $\mathrm{H}$, Isogaya $\mathrm{M}$ and Nagao T: Molecular characterization of pharmacological properties of T-0509 for $\beta$-adrenoceptors. Eur J Pharmacol 315, 363 - 367 (1996)

11 Mizushima S and Nagata S: pEF-BOS, a powerful mammalian expression vector. Nucleic Acids Res 18, 5322 (1990)

12 Kikkawa H, Kurose H, Isogaya M, Sato $\mathrm{Y}$ and Nagao T: Differential contribution of two serine residues of wild type and constitutively active $\beta_{2}$-adrenoceptors to the interaction with $\beta_{2}$-selective agonists. Br J Pharmacol 121, 1059-1064 (1997)

13 Soeder KJ, Snedden SK, Cao W, Della Rocca GJ, Daniel KW, Luttrell LM and Collins S: The $\beta_{3}$-adrenergic receptor activates mitogen-activated protein kinase in adipocytes through a $\mathrm{G}_{\mathrm{i}}$ dependent mechanism. J Biol Chem 274, 12017-12022 (1999)

14 Gerhardt CC, Gros J, Strosberg AD and Issad T: Stimulation of the extracellular signal-regulated kinase $1 / 2$ pathway by human beta-3 adrenergic receptor: New pharmacological profile and mechanism of activation. Mol Pharmacol 55, 255 - 262 (1999)

15 Gauthier C, Tarvernier G, Charpentier F, Langin D and Marec HL: Functional $\beta_{3}$-adrenoceptor in the human heart. J Clin Invest 98, 556 - 562 (1996)

16 Guan XM, Amend A and Strader CD: Determination of structural domains for $\mathrm{G}$ protein coupling and ligand binding in $\beta_{3}$ adrenergic receptor. Mol Pharmacol 48, 492 - 498 (1995)

17 Sunahara RK, Dessauer CW and Gilman AG: Complexity and diversity of mammalian adenylyl cyclases. Annu Rev Pharmacol Toxicol 36, 461 - 480 (1996)

18 Nantel F, Marullo S, Krief S, Strosberg AD and Bouvier M: Cell-specific down-regulation of the $\beta_{3}$-adrenergic receptor. J Biol Chem 269, 13148 - 13155 (1994) 